IZA DP No. 9895

Research Parasites Are Beneficial for the Organism as a Whole: Competition between Researchers Creates a Symbiotic Relationship

Benedikt Fecher

Gert G. Wagner

April 2016 


\title{
Research Parasites Are Beneficial for the Organism as a Whole: Competition between Researchers Creates a Symbiotic Relationship
}

\author{
Benedikt Fecher \\ DIW Berlin, HIIG and Leibniz Association \\ Gert G. Wagner \\ DIW Berlin, MPI for Human Development, TU Berlin and IZA
}

Discussion Paper No. 9895

April 2016

IZA

P.O. Box 7240

53072 Bonn

Germany

Phone: +49-228-3894-0

Fax: +49-228-3894-180

E-mail: iza@iza.org

Any opinions expressed here are those of the author(s) and not those of IZA. Research published in this series may include views on policy, but the institute itself takes no institutional policy positions. The IZA research network is committed to the IZA Guiding Principles of Research Integrity.

The Institute for the Study of Labor (IZA) in Bonn is a local and virtual international research center and a place of communication between science, politics and business. IZA is an independent nonprofit organization supported by Deutsche Post Foundation. The center is associated with the University of Bonn and offers a stimulating research environment through its international network, workshops and conferences, data service, project support, research visits and doctoral program. IZA engages in (i) original and internationally competitive research in all fields of labor economics, (ii) development of policy concepts, and (iii) dissemination of research results and concepts to the interested public.

IZA Discussion Papers often represent preliminary work and are circulated to encourage discussion. Citation of such a paper should account for its provisional character. A revised version may be available directly from the author. 


\section{ABSTRACT \\ Research Parasites Are Beneficial for the Organism as a Whole: Competition between Researchers Creates a Symbiotic Relationship ${ }^{*}$}

In the New England Journal of Medicine, Longo and Drazen critically assessed the concept of data sharing. Their main concern is that a "new class of research person will emerge" that uses data, which were gathered by other researchers, for their own original research questions. The authors referred to this class of researcher as "research parasites". Longo and Drazen are right when they note that scientific data sharing deserves more recognition. However, they indicate that the most adequate form of recognition for data sharing is coauthorship. They suggest to work "symbiotically, rather than parasitically, with the investigators holding the data, moving the field forward in a way that neither group could have done on its own." Although this is true in particular cases, co-authorship as the sole instrument of credit will unnecessarily restrict the potential of data sharing. More suitable instruments for giving credit where credit is due would be a much greater appreciation of data sharing by research communities by introducing citations of data sets, bestowing awards for good datasets, and considering data "production" when assessing scientists' career prospects, funding applications, and research outputs.

JEL Classification: B40, C80, Z11

Keywords: data sharing, incentives, rewards, organism, culture

Corresponding author:

Gert G. Wagner

DIW Berlin

Mohrenstr. 58

10117 Berlin

Germany

E-mail: gwagner@diw.de

\footnotetext{
"A shorter version of this note was published as a letter under the title "A research symbiont" in Science, Vol. 351, Issue 6280, pp. 1405-1406. We thank Jennifer Sills and Roisin Cronin for their skillful edits of the published and the present version.
} 
In the New England Journal of Medicine, Longo and Drazen (1) critically assessed the concept of data sharing (in medicine). Their main concern is that a "new class of research person will emerge" that uses data, which were gathered by other researchers, for their own original research questions. The authors, although indirectly, later referred to this class of researcher as "research parasites".

The label "research parasites" certainly does not reflect the zeitgeist of an increasingly collaborative research era and initiatives towards openness and transparency. But even more importantly, Longo and Drazen (1) miss the very point of scientific research when they write, that the researchers may "even use the data to try to disprove what the original investigators had posited". However, the notion that researchers should take nothing as final truth is at the core of the scientific paradigm. This is what Popper (2) proposed with his critical rationalism and Merton (3) with his conceptualization of skepticism. Longo's and Drazan's (1) proposition to "start with a novel idea, one that is not an obvious extension of the reported work" is misleading. Medical research is particularly likely to derive great benefit from old ideas through meta-analyses and replication studies (4) that use original datasets.

Longo and Drazen make the valid point that researchers might misinterpret data. However, misinterpretation is common in science, and the only measure that can fight misinterpretation is transparency and competition between researchers. Besides, misinterpretations might be a matter of insufficient data documentation by 
the principal investigator. Thus, a culture of data sharing and re-analysis most likely would help to improve the quality of data documentations

And, in fact, the creators of the term "research parasite", Longo and Drazen, miss the core of the scientific paradigm when they write that researchers may "even use the [open] data to try to disprove what the original investigators had posited." Using research data to try to disprove a result is good scientific practice, especially in light of the replication crisis (5-7). Thus it is perfectly understandable when McNutt (8) declares in an editorial in Science that she is proud of being a "research parasite."

Longo and Drazen are right when they note that scientific data sharing deserves more recognition. However, they indicate that the most adequte form of recognition for data sharing is co-authorship. They suggest to work "symbiotically, rather than parasitically, with the investigators holding the data, moving the field forward in a way that neither group could have done on its own." Although this is true in particular cases, co-authorship as the sole instrument of credit will unnecessarily restrict the potential of data sharing and could be a detriment to the original researcher, for instance, if the resulting publications lack quality (9). In the case of replication studies and meta-analyses, co-authorship makes no scientific sense. 
More suitable instruments for giving credit where credit is due $(10,11)$ would be a much greater appreciation of data sharing by research communities by introducing citations of data sets, bestowing awards for good datasets, and considering data "production" when assessing scientists' career prospects, funding applications, and research outputs.

In other words: it is indeed time to develop new metrics for crediting "data production" and "replication efforts". With this end in mind, research parasites are beneficial for the organism as a whole. Competition between researchers and a formalized incentive structure for data producers (and reusers) would create a symbiotic relation between researchers and research parasites.

\section{References}

1.

D. L. Longo, J. M. Drazen, Data Sharing. New England Journal of Medicine. 374, 276-277 (2016).

2.

K. R. Popper, The logic of scientific discovery (Routledge, London; New York, 2002).

3.

R. K. Merton, The sociology of science: theoretical and empirical investigations (University of Chicago Press, Chicago, 1973).

4.

R. Jones, D. Reeves, C. Martinez, Overview of Electronic Data Sharing: Why, How, and Impact. Current Oncology Reports. 14, 486-493 (2012). 
5.

C. F. Camerer et al., Evaluating replicability of laboratory experiments in economics. Science. 351, 1433-1436 (2016).

6.

C. J. Anderson et al., Response to Comment on "Estimating the reproducibility of psychological science." Science. 351, 1037-1037 (2016).

7.

Open Science Collaboration, Estimating the reproducibility of psychological science.

Science. 349, aac4716-aac4716 (2015).

8.

M. McNutt, \#IAmAResearchParasite. Science. 351, 1005-1005 (2016).

9.

. Rohlfing, J.-B. Poline, Why shared data should not be acknowledged on the author byline. Neurolmage. 59, 4189-4195 (2012).

10.

German Data Forum (RatSWD), Building on Progress. Expanding the Research Infrastructure for the Social, Economic, and Behavioral Sciences (Budrich UniPress, Opladen \& Farmington Hills) (2011).

11.

Credit where credit is due. Nature Cell Biology. 11, 1-1 (2009). 